\title{
OPTIMIZING FRANGIBILITY FACTOR OF CU-SN COMPOSITE MATERIAL BY TAGUCHI AND NEURAL NETWORK METHODS
}

\author{
WIDYASTUTI* \\ Department of Materials and Metallurgical Engineering \\ Institut Teknologi Sepuluh Nopember \\ Jl. Teknik Kimia, Keputih, 60111, Surabaya,East Java, Indonesia \\ wiwid@mat-eng.its.ac.id \\ MIA KRISTINA DAMAYANTI \\ Department of Materials and Metallurgical Engineering \\ Institut Teknologi Sepuluh Nopember \\ Jl. Teknik Kimia, Keputih, 60111, Surabaya,East Java, Indonesia \\ mia94kristina@gmail.com \\ MAS IRFAN P. HIDAYAT \\ Department of Materials and Metallurgical Engineering \\ Institut Teknologi Sepuluh Nopember \\ Jl. Teknik Kimia, Keputih, 60111, Surabaya,East Java, Indonesia \\ irfan@mat-eng.its.ac.id \\ HOSTA ARDHYANANTA \\ Department of Materials and Metallurgical Engineering \\ Institut Teknologi Sepuluh Nopember \\ Jl. Teknik Kimia, Keputih, 60111, Surabaya,East Java, Indonesia \\ hostaa@mat-eng.its.ac.id \\ * Corresponding author \\ Published 31 January 2020
}

\begin{abstract}
CuSn composite material is widely applied to fabricate frangible bullets. This work employs secondary data of Frangibility Factor (FF) value. The optimization method for the design is performed with orthogonal array by Taguchi and neural network method. It is obtained that the optimum parameter is combination of $20 \% \mathrm{wt} \mathrm{Sn}$, compaction pressure of 450 $\mathrm{MPa}$ and sintering temperature of $500{ }^{\circ} \mathrm{C}$ with the prediction value of Frangibility Factor (FF) 19.70. The ANOVA analysis for Taguchi shows that the compaction pressure factor is $45.49 \%$, Sn $27.65 \%$ composition and sintering temperature of $21.65 \%$. The result of the optimization design is further confirmed by experiment and yielded an average Frangibility Factor (FF) value of 19.29. From the experimental data, confidence interval test results are accepted because of the interlock interval. It means that the optimization design agrees with the experimental results.
\end{abstract}

Keywords: CuSn; composite materials; powder metallurgy; Taguchi; Neural Network.

\section{Introduction}

$\mathrm{CuSn}$ is composite material that is widely applied to fabricate frangible bullets (Benini Joseph C, 2001). Frangible material is a type of material that it is easily broke when touching hard objects (Joys J, 2009). The ability of the material to break can be calculated by Frangible Factor (FF) in ballistic testing. In the previous results shows that our frangible material gives Frangibility Factor (FF) value of 9.34 when it is heated at temperature of $200{ }^{\circ} \mathrm{C}$ for $30 \mathrm{~min}$ and compaction pressure of $600 \mathrm{MPa}$ (Firmansyah K, Widyastuti., 2015). This value is already qualified as frangible material but it is still lower than commercial frangible bullets (FF equal 126.3). To improve the Frangibility Factor (FF) value can be optimized by increasing the mechanical properties, such as the compression modulus elasticity $(\mathrm{K})$ and compressive strength $(\sigma)$ which can be achieved by 


\section{MATERIALS RESEARCH COMMUNICATIONS 1(1) (2020) 17-25}

Widyastuti et. al.

identifying the type of material used and the manufacturing process through powder metallurgy (German Randall, 1984).

The process of manufacturing through powder metallurgy have four processes to increase the Frangibility Factor (FF) which can affect the mechanical properties of materials. Four processes parameters that have significant effect on product characteristic such as material composition, compaction pressure, sintering temperature and holding time (German Randall, 1984). In the composition of 5-15\% wt Sn and temperature 800$900{ }^{\circ} \mathrm{C}$ provides a pressured 49-214 MPa (Kruachaturrat, S dkk. 2009). At the sintering temperature of 260-300 is formed $\mathrm{Cu}_{3} \mathrm{Sn}$ and $\mathrm{Cu}_{6} \mathrm{Sn}_{5}$ phases which act as brittle intermetallic (Liu dkk, 2012).

The complexity of process for manufacturing frangible materials, it is necessary to find an optimum experimental design for the optimum Frangibility Factor (FF) value. The stage of experimental design is to find the optimum value that gives the best response (Montgomery, D. C. 2012). Therefore, in this work is applied Taguchi and Neural Network methods. In the optimization process for fabrication of frangible material, Taguchi method is capable to evaluate several factors with a minimum number of tests due to the layout of experimental data orthogonal arrays. The Neural Network is also applied in this work for data comparison (Setiawan, B.I., Rudiyanto. 2004). This work aims to optimize the value of Frangibility Factor (FF) based on experimental design. The data source used is secondary data from research lab research team. The optimization process uses the Taguchi and Neural Network methods. The optimization data will be validated through experiment confirmation.

\section{Methods}

\subsection{Parameter Research}

The response parameter used in this study is the Frangibility Factor (FF) value with the maximum value. Using three process parameters namely Sn weight composition, compaction pressure and sintering temperature. With each process parameter level shown in Table 1

Table 1. Combination of parameters process and levels

\begin{tabular}{cccccc}
\hline Factor & Description & Unit & Level 1 & Level 2 & Level 3 \\
\hline $\mathrm{A}$ & Composition \%wt Sn & gr & 20 & 30 & 40 \\
$\mathrm{~B}$ & Compaction pressure & $\mathrm{MPa}$ & 450 & 600 & 750 \\
$\mathrm{C}$ & Sintering Temperature & ${ }^{0} \mathrm{C}$ & 400 & 500 & 600 \\
\hline
\end{tabular}

\subsection{Determination of Degree of Freedom}

The degree of freedom is used to determine the minimum number of experiments to be performed. Table 2 shows the number of variables and levels in each code, which will be used to determine the value of degrees of freedom.

Table 2. Number degree of freedom (DoF)

\begin{tabular}{|c|c|c|c|c|}
\hline No & & System & Number of level & Number of DoF \\
\hline \multirow[t]{2}{*}{1} & Grand Mean & & 1 & 1 \\
\hline & & Composition & 3 & 2 \\
\hline \multirow[t]{2}{*}{2} & Parameter design & Compaction & 3 & 2 \\
\hline & & Sintering & 3 & 2 \\
\hline & & Total & & 7 \\
\hline
\end{tabular}

\subsection{Choosing an Orthogonal Array}

From the calculation of degrees of freedom, the minimum number of experiments is seven times, but in the orthogonal array system there is no L7. So it must be modified where the number of experiments should be more than seven. The appropriate orthogonal array design for 3 levels and 3 factors is L9. Secondary data and research variables are shown in Table 3. 
MATERIALS RESEARCH COMMUNICATIONS 1(1) (2020) 17-25

Widyastuti et. al.

Tabel 3. Experimental design of orthogonal array e

\begin{tabular}{cccccc}
\hline Experimental Number & \multicolumn{2}{c}{$\begin{array}{c}\text { Parameter process } \\
\text { Compaction } \\
\text { pressure }\end{array}$} & $\begin{array}{c}\text { Sintering } \\
\text { Temperature }\end{array}$ & FF & SNR \\
\hline $\mathbf{1}$ & 1 & 1 & 1 & 18.58 & 25.37 \\
$\mathbf{2}$ & 1 & 2 & 2 & 19.20 & 25.66 \\
$\mathbf{3}$ & 1 & 3 & 3 & 17.47 & 24.82 \\
$\mathbf{4}$ & 2 & 1 & 2 & 18.85 & 25.47 \\
$\mathbf{5}$ & 2 & 2 & 3 & 17.22 & 24.70 \\
$\mathbf{6}$ & 2 & 3 & 1 & 16.50 & 24.32 \\
$\mathbf{7}$ & 3 & 1 & 3 & 18.09 & 25.02 \\
$\mathbf{8}$ & 3 & 2 & 1 & 17.30 & 24.68 \\
\hline
\end{tabular}

\section{Results and Discussion}

\subsection{Optimization Results with Taguchi}

Noise ratio is a $\log$ function at the desired output and is used as an objective function for optimization and analysis data (Pardeshi Pankaj, ). The signal represents the desired value for the output characteristic while the noise represents an undesirable value (standard deviation). So Signal to Noise is used to measure the characteristics of the deviation quality from the desired value (Vicko G A, 2014). The desired quality characteristic is chosen by using equation 1 and 2 to obtain the SNR as shown in Table 1

$$
\begin{aligned}
& \text { M.S.D }=\frac{1}{N} \sum_{i=1}^{n}\left(\frac{1}{y_{1}}\right)^{2} \\
& \eta=-10 . \log \text { (M.S.D.) }
\end{aligned}
$$

$\eta: \mathrm{S} / \mathrm{N}$ ratio

$\mathrm{N}$ : number of repetitions of an experiment

$\mathrm{y}: \mathrm{FF}$ value

From the mean and SNR data, the ANOVA calculations are shown in Tables 4 and 5.

Table 4. Calculation result of ANOVA for mean

\begin{tabular}{lccccccc}
\hline \multicolumn{1}{c}{ Source } & SS & DF & MS & F Ratio & SS & \% Contribution & F tabel \\
\hline A & 1.7084 & 2 & 0.8542 & 15.892 & 1.6609 & 24.142 & 5.41 \\
B & 3.2238 & 2 & 1.6119 & 29.989 & 3.1163 & 46.996 & 5.41 \\
C & 1.5912 & 2 & 0.7956 & 14.801 & 1.4830 & 22.375 & 5.41 \\
Eror & 0.1075 & 2 & 0.0537 & 1 & 0.4300 & 6.484 & \\
SS $_{\boldsymbol{t}}$ & 6.6310 & 8 & & & 6.6310 & & \\
Mean & 2856.77 & 1 & & & & & \\
SS $_{\text {total }}$ & 287.842 & 9 & & & & & \\
\hline
\end{tabular}

From the ANOVA (table 4) can be seen that the significant factors influence on the value of Frangibility Factor (FF) is factor B (compression pressure factor) with a large contribution of $46.996 \%$. The result of this contribution is also in accordance with the analysis in Table 4.8 response mean that compaction pressure is ranked first in giving effect to Frangibility Factor $(\mathrm{FF})$ value. This conclusion is also supported by the value of $\mathrm{F}$ ratio of each parameter has a value greater than $\mathrm{F}$ table $(\mathrm{F} 0,05 ; 3 ; 5)=5.41$. 
MATERIALS RESEARCH COMMUNICATIONS 1(1) (2020) 17-25

Widyastuti et. al.

Table 5. ANOVA calculation results for SNR

\begin{tabular}{|c|c|c|c|c|c|c|c|}
\hline Source & SS & DF & MS & F Ratio & SS' & \% Contribution & F tabel \\
\hline$\overline{\mathbf{A}}$ & 0.4697 & 2 & 0.2348 & 22.284 & 0.4487 & 27.654 & 5.41 \\
\hline B & 0.7592 & 2 & 0.3796 & 36.015 & 0.7382 & 45.496 & 5.41 \\
\hline $\mathbf{C}$ & 0.3723 & 2 & 0.1861 & 17.663 & 0.3513 & 21.651 & 5.41 \\
\hline Eror & 0.0211 & 2 & 0.0105 & 1 & 0.0843 & 5.197 & \\
\hline $\mathbf{S S}_{\mathbf{t}}$ & 1.6225 & 8 & & & 1.6225 & & \\
\hline Mean & 5609.730 & 1 & & & & & \\
\hline $\mathbf{S S}_{\text {total }}$ & 5611.352 & 9 & & & & 94.8026 & \\
\hline
\end{tabular}

From the ANOVA table it can be seen that the error value causes deviation or data deviation on the model of $5.19 \%$. Where this value is acceptable because of the Taguchi error conditions maximum 50\%. Optimization of Taguchi calculations using the Mean response table shown in Table 6.

Table 6. Response Table Means and FF value

\begin{tabular}{|c|c|c|c|}
\hline Level & Komposisi \%wt Sn & Tekanan Kompaksi & Temperatur Sintering \\
\hline 1 & 18.43 & 18.50 & 17.47 \\
\hline 2 & 17.51 & 17.91 & 18.41 \\
\hline 3 & 17.51 & 17.04 & 17.57 \\
\hline Delta & 0.93 & 1.46 & 0.94 \\
\hline Rank & 3 & 1 & 2 \\
\hline
\end{tabular}

From Table 6, it can be seen that each variable that has the optimum value is the composition \% wt Sn at level 1 of 18.43 , the compaction pressure at level 1 is 18.50 and the sintering temperature at level 2 is 18.41 , which then this value is used to find the optimization value as shown in the calculations below

$$
\begin{array}{ll}
\mathrm{FF} & =\mathrm{A}_{1}+\mathrm{B}_{1}+\mathrm{C}_{2}-2 \mathrm{~T} \\
\mathrm{FF} & =18.43+18.50+18.41-2 \times 17.81 \\
\mathrm{FF} & =19.70
\end{array}
$$

\subsection{Optimization Results with Neural Network Method}

The artificial neural network (ANN) system is a physical cell system which can store and utilize experimental information. The power of learning on algorithms and self-organizing abilities allows ANN to adapt to the environment. After doing Taguchi analysis, then approach the pattern of experimental results by using Artificial Neural Network. In this case the authors want to analyze the performance of artificial neural network by back propagation method in predicting the coefficient of Frangibility Factor (FF) value.

\subsubsection{Data Training Process}

In this study, feedforward NN based on Multi Layer Perceptron (MLP) is employed. The first layer consists of a layer receiving a set of inputs and the final layer acts as the output (target) layer. Hidden layers connect the input and output layers (Hidayat, 2015). Backpropagation (BP) algorithm is commonly employed for the MLP based NN. The training process in BP requires three stages: feed forward input data for training, back propagation for error values and adjustment of the weight value of each node at each layer on ANN. The design of this network structure and architect is shown in Figures 1 and 2. 
MATERIALS RESEARCH COMMUNICATIONS 1(1) (2020) 17-25

Widyastuti et. al.

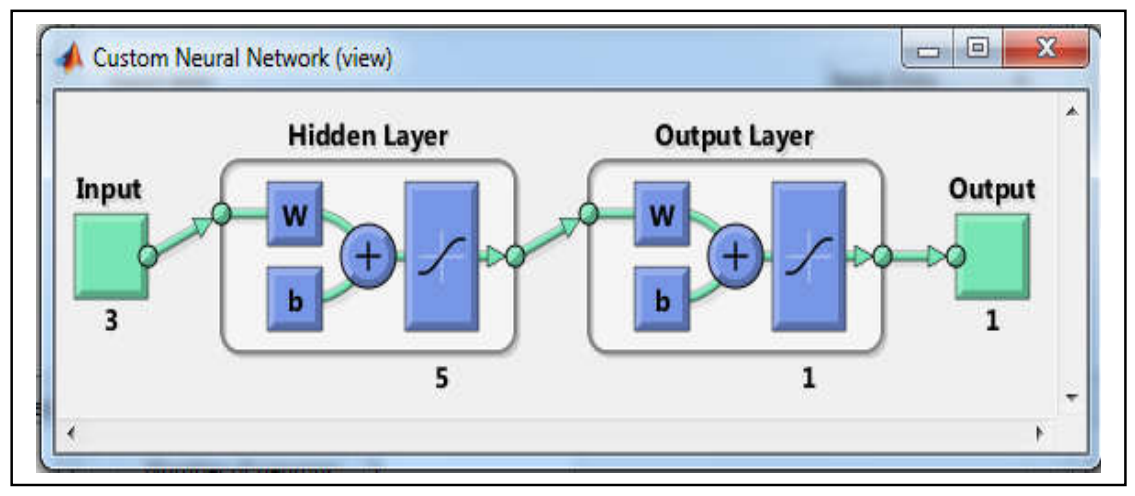

Fig. 1. Design network structure of ANN.

Determination of model weight depends on the study of learning parameters. The learning parameters used with traingdx are:

- Tolerance of error : 0,01

- Learning rate $(\alpha) \quad: 0,5$

- Number of Iteration : 1.000

- Maximum epoch : 10.000

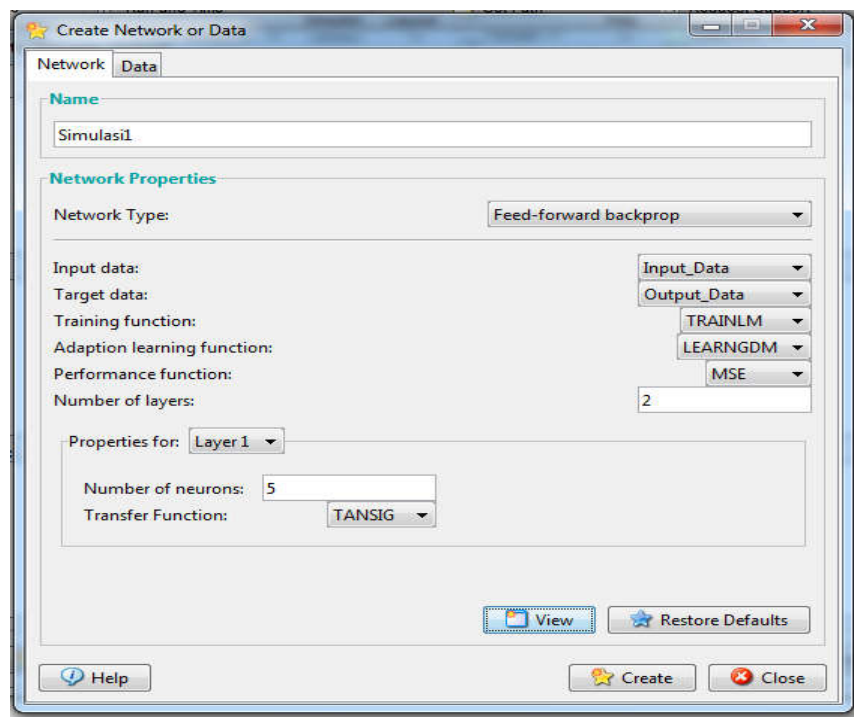

Fig. 2. Network architecture of ANN.

Model conformity test is done to find out if the error on the model has noise or not. This test is viewed from the Auto Correlation Function (ACF) plot and Partial Auto Correlation Function (PACF) of the errors generated in the learning data shown in Figure 3 (a) for ACF and 3 (b) for PACF. 
MATERIALS RESEARCH COMMUNICATIONS 1(1) (2020) 17-25

Widyastuti et. al.
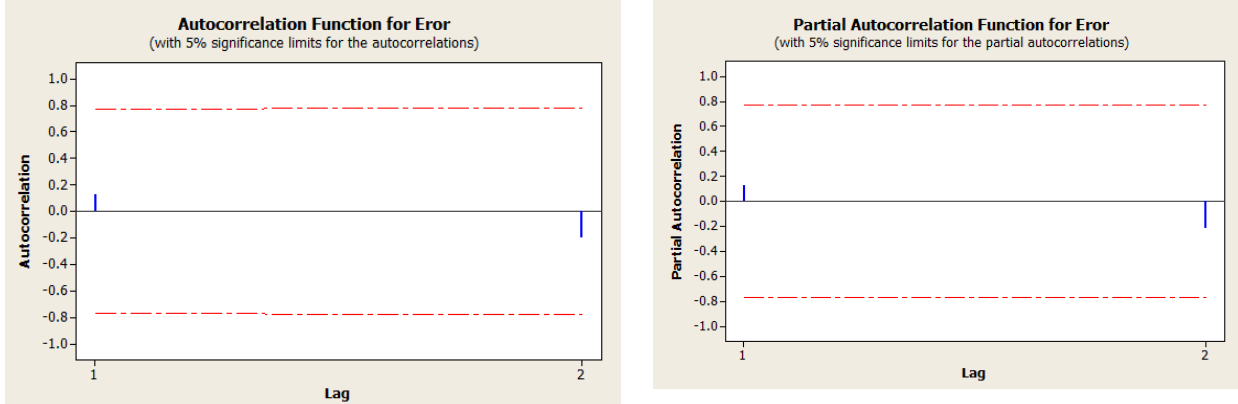

Fig. 3. Plot a). ACF b). PACF model FFNN Back propagation algorithm with 5 neurons in hidden layer and $x 1, x 2, x$ as input.

In Figure 3 shows that the correlation is at each the intervals. This means that the training process in this lesson has been conducted independently and there is no correlation between the training. The results of data testing using ANN are shown in Table 7. The data in Table 7 is also done first denormalization process. It can be seen that from predicted neural network the optimum Frangibility Factor (FF) value occurs in combination of process parameters Composition 20\% wt Sn, Compression Pressure $450 \mathrm{MPa}$, Sintering Temperature $400 \mathrm{oC}$. The value of the optimum combination of process parameters is consistent with the predicted results in the Taguchi method.

Table 7. Input data used to predict targets

\begin{tabular}{ccccc}
\hline No. experiment & $\begin{array}{c}\text { Composition \%wt } \\
\text { Sn }\end{array}$ & $\begin{array}{c}\text { Compaction } \\
\text { pressure } \\
\text { MPa }\end{array}$ & $\begin{array}{c}\text { Sintering } \\
\text { Temperature }{ }^{\mathbf{0}} \mathbf{C}\end{array}$ & FF Value \\
\hline 10 & 20 & 450 & 400 & 19.0240 \\
11 & 20 & 450 & 600 & 18.9807 \\
12 & 20 & 600 & 400 & 18.5258 \\
13 & 20 & 600 & 600 & 18.6524 \\
14 & 20 & 750 & 400 & 17.4463 \\
15 & 20 & 750 & 500 & 17.8023 \\
16 & 30 & 450 & 400 & 18.3704 \\
17 & 30 & 450 & 600 & 18.6909 \\
18 & 30 & 600 & 400 & 17.0295 \\
19 & 30 & 600 & 500 & 17.8615 \\
20 & 30 & 750 & 500 & 17.0778 \\
21 & 30 & 750 & 600 & 17.1057 \\
22 & 40 & 450 & 400 & 17.9846 \\
23 & 40 & 450 & 500 & 18.0582 \\
24 & 40 & 600 & 500 & 17.1981 \\
25 & 40 & 600 & 600 & 17.0968 \\
26 & 40 & 750 & 400 & 16.7555 \\
27 & 40 & 750 & 600 & 17.1332 \\
\hline
\end{tabular}


MATERIALS RESEARCH COMMUNICATIONS 1(1) (2020) 17-25

Widyastuti et. al.

\subsubsection{Confirmation Experiment}

Confirmation of this experiment is carried out on a combination of process parameters that give optimum value and one other combination to determine whether the reality value is in accordance with the predictive value of test results using the Artificial Neural Network. Each experiment is carried out five repetitions of data retrieval.

From optimization result by using Taguchi method combination of process parameters giving optimum value that is A1B1C2 with parameter composition $20 \%$ wt $\mathrm{Sn}$, compressor pressure $450 \mathrm{MPa}$ and at sintering temperature $500{ }^{\circ} \mathrm{C}$, which will be coded 1 . This combination is also designated as optimum combination on result testing with artificial neural network (ANN) method. Furthermore, to know the learning ability of ANN also confirmation of experiment on other combination, that is $\mathrm{A} 1 \mathrm{~B} 3 \mathrm{C} 2$ with parameter composition $20 \% \mathrm{wtSn}$, compressive pressure $750 \mathrm{MPa}$ and at sintering temperature $500{ }^{\circ} \mathrm{C}$, which will be coded 2 . This combination is chosen to compare the value of Frangibility Factor (FF) result testing in ANN with reality. The result of calculating the next Frangibility Factor (FF) value is shown in Table 8.

Table 8. Calculation of FF values

\begin{tabular}{cccc}
\hline Code & FF Value & Code & FF Value \\
\hline 1A & 19.04248 & $2 \mathrm{~A}$ & 15.69379 \\
1B & 19.01470 & $2 \mathrm{~B}$ & 16.67162 \\
1C & 19.19997 & $2 \mathrm{C}$ & 16.72649 \\
1D & 20.09245 & $2 \mathrm{D}$ & 16.96208 \\
1E & 19.07953 & $2 \mathrm{E}$ & 17.52959 \\
\hline Mean & 19.29 & Mean & 16.72 \\
\hline
\end{tabular}

\subsubsection{Calculation of Confidence Interval}

Confidence interval or confidence interval is used to explain the appropriateness of the confirmation experiment to the optimization result. The result of the confirmation experiment is categorized according to the result of the response variable's automation if the average of the confirmation experiment results in the estimate of the average response duration at the optimum condition, or if the average confidence interval of the experimental results with the estimated average of the confirmation experiments intersects.

Confidence interval values for quality characteristics were calculated using equation (3)

$$
C I= \pm \sqrt{F_{\propto, v 1, v 2}} \times V e \times\left[\frac{1}{n_{e f f}}+\frac{1}{r}\right]
$$

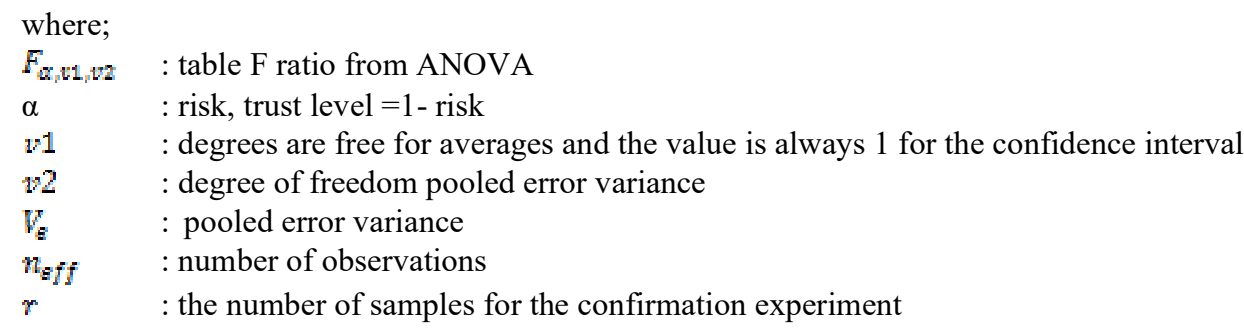


MATERIALS RESEARCH COMMUNICATIONS 1(1) (2020) 17-25

Widyastuti et. al.

The results of the confidence interval calculation for optimal conditions and confirmation values are shown in Table 9.

Tabel 9. Results of confidence interval

\begin{tabular}{ccc}
\hline Value & \multicolumn{2}{c}{ Confidence Interval } \\
\cline { 2 - 3 } & Optimal value predicted results & Confirmation of experiment results \\
\hline Mean Taguchi & $19.224 \leq \mu \leq 20.175$ & $18.76 \leq \mu \leq 19.78$ \\
Mean NN & $18.78 \leq \mu \leq 19.258$ & $18.76 \leq \mu \leq 19.78$ \\
SNR Taguchi & $25.68 \leq \eta \leq 26.11$ & $25.45 \leq \eta \leq 25.93$ \\
Mean NN & $17.56 \leq \mu \leq 18.03$ & $16.42 \leq \mu \leq 17.013$ \\
\hline
\end{tabular}

Furthermore, to facilitate the interpretation of the results of the calculation of the confidence interval depicted in Table 10.

Table 10. Comparison of confidence interval values

\begin{tabular}{|c|c|c|c|}
\hline Value & Comparison & Note & Decision \\
\hline \multirow{3}{*}{ Mean Optimum } & $19.22 \bigcirc 20.17$ & Prediction & \multirow{3}{*}{ Accepted } \\
\hline & $18.78 \bigcirc-19.25$ & $\mathrm{NN}$ & \\
\hline & $18,76 \bigcirc 19,78$ & Experiments & \\
\hline \multirow[t]{2}{*}{ SNR Optimum } & $25,68 \bigcirc 26.11$ & Prediction & \multirow{2}{*}{ Accepted } \\
\hline & $25.45 \circ \longrightarrow 25,93$ & Experiment & \\
\hline \multirow[t]{2}{*}{ Mean treatment 2} & $17,56 \bigcirc 1803$ & Prediction & \multirow{2}{*}{ Rejected } \\
\hline & $16,42 \bigcirc 17.01$ & Experiment & \\
\hline
\end{tabular}

From Table 10 it can be seen that there is a confidence interval value for predicted mean and SNR with confirmation experiments, so that the experiment can be accepted.

From the above test data can be seen the correlation with each process parameter that affect the nature of the composite material. The influence of compaction pressure on the bullet properties frangible can be seen from the role of compaction in providing local deformation effects between contacts that give stain hardening effect and allowing for new contacts to form the distance between the closer particles. in increasing strength, density, shape and dimensional control (German, 1984). Because the characteristics of the frangible bullet are influenced by the mechanical properties of bullets, bullet dimensions, and bullet shapes. Frangibility increases as the strength and toughness of the material decreases. (Rydlo, 2010) The influence of the three factors made in the research process parameters actually contributes directly to the properties of the frangible bullet. The influence form of wt $\mathrm{Sn} \%$ composition and compaction pressure has been described previously in its effect on density. The effect of sintering temperatures in general is to contribute to the movement of atoms forming a formation to unite bonds between particles. The material will increase its strength and other properties (German, Randall M, 1984). This increase in mechanical properties is also affected by the second or intermetallic phase compounds formed (Han et al., 2014). The intermetallic phase is formed during the sintering process, the presence of the liquid phase (melting Sn) plays a role in the wetting process and will form a particular bond that will increase the strength of the inter particle bond (Montgomery,2012). The intermetallic phase name formed acts as a binder material that bridges between copper particles that are not metallically bonded (Banovic and Mates, 2008). 
MATERIALS RESEARCH COMMUNICATIONS 1(1) (2020) 17-25

Widyastuti et. al.

\section{Conclusions}

In this works shows that result of calculation of ANOVA for mean value at Taguchi demonstrates the compaction pressure factor is the most influential equal to $45.49 \%$, composition of $\mathrm{Sn} 27.65 \%$ and sintering temperature $21.65 \%$. The optimization result of Frangibility Factor (FF) value is at combination of $5 \%$ wt $\mathrm{Sn}$, $200 \mathrm{MPa}$ compaction pressure and sintering temperature $250{ }^{\circ} \mathrm{C}$ with prediction of Frangibility Factor (FF) value by Taguchi 19.70 and NN value Frangibility Factor (FF) 19.02. This is indicating that the Taguchi and NN methods were able to optimize the Frangibility Factor (FF) value.

\section{References}

Banovic, S.W. and Mates, S.P. (2008), "Microscopic fracture mechanisms observed on $\mathrm{Cu}-\mathrm{Sn}$ frangible bullets under quasi-static and dynamic compression”, J Mater Sci, Vol. 43, pp. 4840-4848.

Benini, J.C. (2001). Frangible Metal Bullets, Ammunition, and Method of Making Such Articles. USA. Patent: US 6,263,798 B1.

Firmansyah, K. Widyastuti. (2015). "Pengaruh Temperatur Sintering Metode Metalurgi Serbuk Terhadap Frangibility dan Performa Balistik Peluru Frangible Komposit Cu-10\% wt Sn". ITS, Surabaya.

German, R. M. (1984). Powder Metallurgy Science. (USA: Metal powder Industries Federation)

Han, P., Xiao, F.R., Zou, W.J. and Liao, B. (2014), "Influence of Hot Pressing Temperature on the Microstructure and Mechanical Properties of 75\% Cu- $25 \%$ Sn Alloy", Materials and Design, Vol. 53, pp. $38-42$

Joys, J. (2009). Lead Free Frangible Bullets. USA. Patent: US 8,225,718 B2

Kruachaturrat, S., Thanomsilp, C. and Wattanasiriwech, S. (2009). "Sintering Cu-Sn Materials for Frangible Bullets" The 3rd Thailand Metallurgy Conference (TMETC-3): Metallurgical Research for Thailand Development. Bangkok, Thailand.

Han, P., Xiao, F.R., Zou, W.J. and Liao, B. (2012), "Intermetallic Compound Formation Mechanisms for Cu-Sn Solid-Liquid Interdiffusion Bonding", Journal of Electronic Materials, Vol. 41, pp. 2453-2462.

Montgomery, D. C. (2012). "Design and Analysis of Experiments (8th edition)". Arizona State: John Wiley \& Sons, Inc.

Pardeshi, P.M., Mungray, A.A. and Mungray, A.K. (2016), "Determination of optimum conditions in forward osmosis using a combined Taguchi-neural approach", Chemical Engineering Research and Design, Vol. 109 , pp. 215-225.

Rydlo, M. (2010), "Theoretical Criterion for Evaluation of the Frangibility Factor", Advances in Military Technology, Vol.5, No. 2, pp. 57-67.

Setiawan, B.I., Rudiyanto. (2004). “Aplikasi Neural Networks Untuk Prediksi Aliran Sungai”. Prosiding Semiloka Teknologi Simulasi dan Komputasi serta Aplikasi 2004 - BPPT, Jakarta.

Vicko G. A. (2014 ). "Pengaruh Temperatur Sintering terhadap Densitas dan Kekerasan Komposit Cu-Sn untuk Aplikasi Proyektil Peluru Frangible dengan Metode Metalurgi Serbuk”. ITS, Surabaya.

Hidayat M.I.P. (2015) System Identification Technique and Neural Networks for Material Lifetime Assessment Application. In: Zhu Q., Azar A. (eds) Complex System Modelling and Control Through Intelligent Soft Computations. Studies in Fuzziness and Soft Computing, Vol 319. Springer, Cham. 